\title{
Siblings' Premarital Childbearing and the Timing of First Sex in Three Major Cities of Côte d'Ivoire
}

By Nafissatou Diop-Sidibé

Nafissatou DiopSidibé is research and evaluation officer, Johns Hopkins

Bloomberg School of Public Health/Center

for Communication Programs, Baltimore, MD, USA.

CONTEXT: The association between youths' sexual and reproductive attitudes and behaviors and those of their peers and parents has been documented; however, information on siblings' influence is scarce, especially for developing countries.

METHODS: Data on 1,395 female and 1,242 male survey respondents aged 15-24 from three cities in Côte d'Ivoire were analyzed. Life-table analysis was conducted to examine respondents' probability of remaining sexually inexperienced according to siblings' history of premarital childbearing. Cox multivariate regressions were used to estimate respondents' relative risks of sexual debut by age 17 and by age 24.

RESULTS: At any age between 15 and 24 years, the life-table probability of remaining sexually inexperienced was typically lower among persons who had at least one sibling with a premarital birth than among those who had no such sibling. In general, among those with at least one sibling who had had a premarital birth, the probability was lower if the sibling or siblings and the respondent were of the same gender rather than opposite genders, and the probability was lowest among those who had a brother and a sister with a history of premarital childbearing. In the multivariate analysis for males, having one or more brothers only, or having at least one brother and at least one sister, with a history of premarital childbearing was associated with increased relative risks of being sexually experienced by ages 17 and 24. No such association was found for females.

CONCLUSION: Programs that seek to reduce premarital sexual activity among young people should develop strategies that take into account the potential influence of siblings.

International Family Planning Perspectives, 2005, 31(2):54-62

In many families around the world, older children, particularly sisters, look after their younger siblings to help their parents, who may be busy with household chores or outside work. In such families, an older child can be an important role model for younger siblings during their early years of life and, thus, influence their behavior. As the younger children grow up, however, and begin to spend more time with their peers and become exposed to external pressures, siblings have less influence on their attitudes and behavior. But does that influence disappear totally?

Social learning theory postulates that people learn how to behave by watching others (models), observing and evaluating the consequences of modeled behaviors, and then reenacting those behaviors. ${ }^{1}$ For many children, the family is the primary environment where they learn how to socialize and behave, and research generally concurs that siblings influence each other in many areas, including sexuality and reproduction. For example, in a review of more than 200 studies conducted in the United States, Kirby noted that having an older sister who had given birth as an adolescent was associated with initiation of sex, frequency of intercourse, pregnancy and childbearing; other significant sibling-related antecedents of adolescents' sexual initiation were number of siblings, being a younger sibling and having an older sister who had had sex. ${ }^{2}$ Similarly, a nation- ally representative study of Ghanaian youth aged 12-24 years found that those with a sister who had been pregnant before marriage were more likely than others to have had sex, had an elevated number of lifetime partners and were more likely than others to have been pregnant. ${ }^{3}$ Kiragu and colleagues reported that the person with whom Kenyan females aged 15-19 felt most comfortable discussing sexual matters was a sister; males of the same age-group named a brother. ${ }^{4}$ Rwenge found that adolescents in Bamenda, Cameroon, talk about their first sexual experience with friends and older siblings. ${ }^{5}$

However, the magnitude of the sibling effect has varied among studies. For example, in a study of adolescent sibling pairs in the United States, younger siblings' sexual behavior was influenced by older relatives' behaviors but not their attitudes. ${ }^{6}$ Adolescents with sexually active older siblings were 2.5 times as likely as other adolescents to be sexually active; gender-specific analysis revealed that the association was statistically significant for older brothers but not for older sisters. East examined a sample made up mainly of black and Hispanic sibling pairs in San Diego, California, and, using a series of scales, computed mean scores on several attitudinal and behavioral outcomes. ${ }^{7}$ She concluded that both attitudes and behaviors of older sisters significantly influenced the younger siblings. Compared 
with females with a never-pregnant older sister, females with a pregnant or parenting older sister were more likely to be accepting of teenage sex and childbearing, placed a lower value on education and career, and were more likely to engage in delinquent behaviors. Females with parenting older sisters were nearly five times as likely as other females to have had sex themselves and to have done so more frequently. The picture was similar for males with a pregnant or parenting older sister: Compared with males with a neverpregnant older sister, they were more likely to be accepting of premarital childbearing, to perceive childbearing as conferring high status and to have reduced self-esteem; they also reported a higher number of problems at school.

In other studies, a sibling effect was not found or was weak. For example, Powers and Cherng-tay Hsueh examined a nationally representative sample of sibling pairs in the United States and found that the influence of the older sister's premarital childbearing on the timing of the younger sister's was overestimated when the "shared unmeasured family-level traits are ignored." ${ }^{8}$ Nevertheless, they concluded that "because the older-sibling effect is large when other sources of variability in premarital birth timing are controlled, interventions may be effective in reducing premarital births among young women in high-risk families." Analyzing data from a nationally representative survey in the United States, Miller and Bingham found only weak evidence of correlation between female adolescents' sexual experience and sibling constellation-including number and gender of siblings and birth order. ${ }^{9}$

In traditional societies in Sub-Saharan Africa, premarital childbearing was rare because marriage was universal and occurred at an early age, especially for females. However, as Meekers has noted, "with increasing modernization the traditional values have gradually deteriorated, or more precisely, they are in the process of adapting to a new socioeconomic environment.... The traditional controls of female sexuality are weakening, sexual freedom is increasing, and new forms of unions are emerging." 10 Consequently, premarital childbearing is becoming increasingly common, particularly in urban areas. In a 2001 chartbook on youth sexual experience and reproductive health in 11 SubSaharan African countries, ${ }^{11}$ Côte d'Ivoire had the highest proportion of sexually experienced, never-married women aged $15-19$ years (45\%); it also had the biggest difference between the proportion of women aged 20-24 who had had sex before age 18 and the proportion who had been married before age 18 ( $82 \%$ vs. 44\%). Moreover, despite declining birthrates over the previous five years among 15-19-year-old females, 30\% of unmarried 18-year-old women in Côte d'Ivoire were mothers or were pregnant with their first child-again, the highest proportion among the countries examined. These indicators of sexual activity and reproduction among young people in Côte d'Ivoire raise particular interest for in-depth analysis of the possible determinants of age at sexual debut.

In the developing world, the influence of peers and parents on youths' attitudes and behaviors regarding sexual- ity and reproduction has been documented. ${ }^{12}$ However, information on the influence of siblings is scarce, and the debate is ongoing.

\section{METHODS}

This study involves a secondary analysis of data collected in November and December 2001 to provide baseline information for a multimedia health communication campaign on youth behavior regarding sexually transmitted infections (STIs), including HIV/AIDS. ${ }^{* 13}$ By using multistage sampling techniques, representative samples of youth aged 15-24 were drawn independently from Abidjan, the commercial and administrative center of Côte d'Ivoire, and two other major cities, Bouaké and Korhogo. About half the sample came from Abidjan; roughly one-quarter each came from the two other cities. In all, 1,419 females and 1,262 males were surveyed.

In this study, participants were grouped according to sibling category: has no sibling with a history of premarital birth (or has no siblings at all); ${ }^{\dagger}$ has one or more brothers, but no sisters, with a history of premarital birth; has one or more sisters, but no brothers, with a history of premarital birth; or has at least one sibling of each gender with a history of premarital birth.

The analyses were performed in three phases. First, descriptive and bivariate analyses were conducted to explore participants' characteristics by sibling category. Second, the probability of remaining sexually inexperienced at each age was estimated for each of the four study groups (i.e., for each sibling category) by using life-table survival analysis. $^{14}$

Although most youth in the sample were single (84\% of females and $97 \%$ of males), information on all youth was used, regardless of marital status. Several reasons justify this choice. For example, premarital sexual activity is sometimes a precipitating factor for early marriage, especially for females. In addition, although some married youth may have had their sexual debut in marriage, nationally representative data from the 1998-1999 Demographic and Health Survey (DHS) for Côte d'Ivoire indicate that women's median age at first sex was 16 years and at first union was 19 years. ${ }^{15}$ The corresponding ages for men were 19 and 26 years. Unfortunately, the data set used for the current study contains no information on age at marriage. However, an analysis of age at first sex indicates that the medi-

*The Ecole Nationale Supérieure de Statistique et d'Economie Appliquée of Abidjan, Côte d'Ivoire, conducted the research for the project Santé Familiale et Prévention du SIDA (Family Health and AIDS Project). Tulane University, New Orleans, LA, USA, and the Johns Hopkins Bloomberg School of Public Health/Center for Communication Programs, Baltimore, MD, USA, provided technical assistance. This project covered eight countries in West and Central Africa. At the time of the survey, it was based in Abidjan.

tIn this study, young people without any siblings $(\mathrm{N}=18)$ were classified with those who said that none of their siblings had had a premarital birth because one can assume no direct or indirect sibling influence on the young people's sexual behavior. Respondents who did not know whether a brother or a sister of theirs had had a premarital birth $(\mathrm{N}=42)$ were excluded, to eliminate any potential bias due to subtle or unacknowledged influence. 
FIGURE 1. Percentage distribution of youth aged 15-24, by siblings' history of premarital childbearing, according to gender of respondent, Family Health and AIDS Project baseline survey, Côte d'Ivoire, 2001

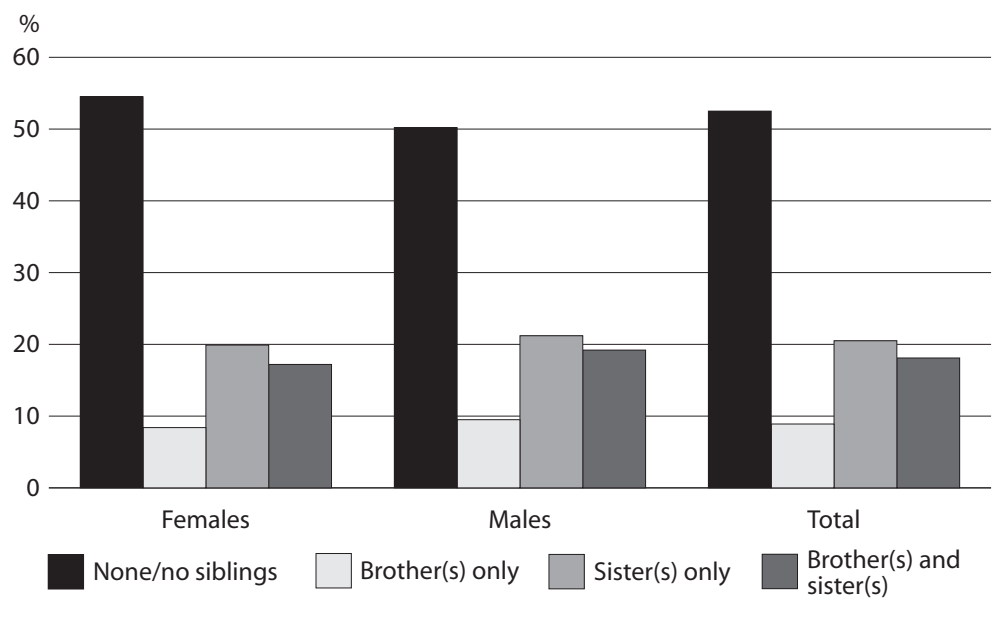

an age at first sex was 16 years for never-married females and 17 years for ever-married females. The median age for both ever- and never-married males was 16 years. These figures are similar to or lower than those derived from the DHS. Therefore, retaining married youth in the sample should not introduce a bias regarding the onset of sexual activity; yet excluding married participants from the analysis could underestimate the strength of the relationships.

The life tables used the following variables: age at first sex and sibling category. For sexually experienced respondents, their age at first sexual relations marked their dropout from the life-table survival analysis; for sexually inexperienced youth, the data were censored at their current age. A binary control variable was used to indicate whether the respondent's age at first sex represents dropout or censoring. Log-rank tests of homogeneity were conducted to determine whether differences among study groups were statistically significant.

In the third phase of the analysis, the potential association between a participant's age at first sex and sibling category was examined by using bivariate and multivariate Cox regressions with backward selection. Variables significant at $\mathrm{p} \leq 10$ were included in the multivariate analyses, but only those significant at $\mathrm{p} \leq .05$ entered the final models.

The conceptual framework used in this analysis draws on social learning theory. ${ }^{16}$ Although a person's age at first sex is affected in part by his or her personal characteristics, social learning theory would emphasize the impact of role

*The characteristics of the father, the mother, and the uncles or aunts will also serve to control for the shared family-level traits of the respondents and their siblings.

†"Don't know" responses are classified as "other" or with the categories that have the least influence on the relationship between the explanatory variable and the outcome. For example, "don't know" responses for highest level of education attended are grouped with "primary, no schooling or informal schooling only." They are grouped with "does not agree" for participants' perception that a pregnancy may affect their life, and with "other" for student or worker status and for participants' perception about role models' approval of their sexual abstinence and opinion about their sexual behavior. models-significant others whom the young person looks up to-and their characteristics, attitudes and behaviors. Young persons' role models generally include their parents; siblings; other close relatives, such as uncles and aunts (who traditionally play an important role in African children's education); and peers-in particular, their close friends. Obviously, there are some interrelations among the role models. Parents and other relatives influence a youth directly but also do so indirectly through their effect on the youth's siblings (shared family-level traits). Similarly, other relatives can influence the youth's parents as part of their role in the upbringing and education of kin's children. Background variables that affect all the actors include the political, economic and legal environments; social and cultural norms; and degree of media exposure.

The analyses use self-reported information on the respondents and their siblings, parents, other relatives and close friends. ${ }^{*}$ Respondent characteristics include: city of residence, educational level, work or school status, religion, religiosity, ethnic group, current marital status, rural or urban residence during childhood (through age 12), the caretaker (or caretakers) whom the respondent primarily lived with during childhood and the person currently in charge of the respondent. Other variables indicate whether respondents agree that a pregnancy at this stage of their life would be disastrous or would likely jeopardize their professional goals, and respondents' perceived degree of risk for AIDS. Further variables indicate respondents' perceived self-efficacy to resist having sex if they were uninterested-specifically, if the potential partner were someone they had known for only a few days or for more than three months; someone whom they "loved dearly"; someone who would give them gifts; or someone who had authority over them, such as a professor or employer.

The following three variables are examined for each type of role model: the respondents' perception of the role model's approval of their being sexually abstinent until marriage, whether the role model's opinion about the respondents' sexual behavior is very important to them, and whether the respondents had had any discussion with the role model in the past 12 months on avoiding or delaying sex. Other characteristics included are the educational levels of the respondents' mother and father, the respondents' number of close friends and the respondents' perception of the proportion of their close, single friends of each gender who have ever had sex. ${ }^{\dagger}$

After the exclusion of respondents who did not know whether a brother or a sister had experienced premarital childbearing, the sample for this study comprised 1,395 females and 1,242 males. All analyses were performed separately by gender.

\section{RESULTS}

\section{Study Participants}

About half the sample had no sibling with a history of premarital childbearing (Figure 1). Among those who did, the most frequently reported scenario was that only a sister 

TABLE 1. Social and demographic characteristics of youth aged 15-24, according to siblings' history of premarital childbearing and gender of respon-
dent, Family Health and AIDS Project baseline survey, Côte d'Ivoire, 2001

\begin{tabular}{|c|c|c|c|c|c|c|c|c|c|c|}
\hline \multirow[t]{3}{*}{ Characteristic } & \multirow{2}{*}{\multicolumn{2}{|c|}{ All respondents }} & \multicolumn{8}{|c|}{ Respondents, according to sibling with premarital birth } \\
\hline & & & \multicolumn{2}{|c|}{ None/no siblings } & \multicolumn{2}{|c|}{ Brother(s) only } & \multicolumn{2}{|l|}{ Sister(s) only } & \multicolumn{2}{|c|}{ Brother(s) and sister(s) } \\
\hline & $\begin{array}{l}\text { Female } \\
(\mathrm{N}=1,395) \neq\end{array}$ & $\begin{array}{l}\text { Male } \\
(\mathrm{N}=1,242) \S\end{array}$ & $\begin{array}{l}\text { Female } \\
(\mathrm{N}=760)+\dagger\end{array}$ & $\begin{array}{l}\text { Male } \\
(\mathrm{N}=623)\end{array}$ & $\begin{array}{l}\text { Female } \\
(\mathrm{N}=117)\end{array}$ & $\begin{array}{l}\text { Male } \\
(\mathrm{N}=118)\end{array}$ & $\begin{array}{l}\text { Female } \\
(\mathrm{N}=278) \neq \neq\end{array}$ & $\begin{array}{l}\text { Male } \\
(\mathrm{N}=263) \S \S\end{array}$ & $\begin{array}{l}\text { Female } \\
(N=240) \S \S\end{array}$ & $\begin{array}{l}\text { Male } \\
(\mathrm{N}=238)+\ddagger\end{array}$ \\
\hline \multicolumn{11}{|l|}{ MEAN (SD) } \\
\hline Age (yrs.) & $18.8(2.7)$ & $19.1(2.7)^{* *}$ & $18.4(2.7)$ & $18.6(2.6)$ & $19.2(2.7)$ & $19.4(2.7)$ & $19.1(2.7)$ & $19.3(2.7)$ & $19.7(2.7)$ & $20.1(2.4) \dagger$ \\
\hline \multicolumn{11}{|c|}{$\begin{array}{l}\text { \% DISTRIBUTION } \\
\text { City }\end{array}$} \\
\hline Abidjan & 54.5 & $46.9 * * *$ & 51.5 & $40.3^{* * *}$ & 59.8 & 52.5 & 52.9 & 53.2 & 63.4 & $54.2^{*}$ \\
\hline Bouaké & 23.8 & 25.0 & 25.0 & 27.9 & 23.1 & 19.5 & 23.4 & 24.0 & 20.8 & 21.4 \\
\hline Korhogo & 21.7 & $28.1^{* * *}$ & 23.5 & $31.8^{* * *}$ & 17.1 & $28.0^{*}$ & 23.7 & 22.8 & 15.8 & $24.4^{*}$ \\
\hline \multicolumn{11}{|c|}{ Educational level } \\
\hline sprimary & 56.2 & $28.6^{* * *}$ & 55.9 & $29.0^{* * *}$ & 53.0 & $33.9^{* *}$ & 56.5 & $24.7^{* * *}$ & 58.3 & $29.0^{* * *}$ \\
\hline Secondary & 39.1 & $62.5^{* * *}$ & 39.2 & $63.6^{* * *}$ & 40.2 & $60.2^{* *}$ & 40.3 & $64.6^{* * *}$ & 37.1 & $58.4^{* * *}$ \\
\hline >secondary & 4.7 & $8.9^{* * *}$ & 4.9 & $7.4 \dagger$ & 6.8 & 5.9 & 3.2 & $10.7^{* * *}$ & 4.6 & $12.6^{* *}$ \\
\hline \multicolumn{11}{|c|}{ School/employment status } \\
\hline Student & 33.6 & $58.9^{* * *}$ & 37.2 & $63.4^{* * *}$ & 29.9 & $50.8^{* *}$ & 31.3 & $58.2^{* * *}$ & 26.5 & $51.7^{* * *}$ \\
\hline Employed & 38.5 & $31.8^{* * *}$ & 35.5 & $28.4^{* *}$ & 43.6 & 35.6 & 38.5 & 33.7 & 45.4 & $37.0 \dagger$ \\
\hline \multicolumn{11}{|l|}{ Neither/does } \\
\hline not know & 27.9 & $9.3^{* * *}$ & 27.3 & $8.2^{* * *}$ & 26.5 & $13.6^{*}$ & 30.2 & $8.1 * * *$ & 28.1 & $11.3^{* * *}$ \\
\hline \multicolumn{11}{|l|}{ Religion } \\
\hline Christian & 51.3 & $41.1^{* * *}$ & 48.6 & $37.6^{* * *}$ & 50.4 & 44.9 & 53.6 & $46.0+$ & 57.5 & $43.3^{* *}$ \\
\hline Muslim & 30.4 & $35.2^{* *}$ & 33.8 & $39.8^{*}$ & 30.8 & 31.4 & 26.3 & 30.0 & 24.2 & 30.7 \\
\hline Other & 18.3 & $23.7^{* * *}$ & 17.6 & $22.6^{*}$ & 18.8 & 23.7 & 20.1 & 24.0 & 18.3 & $26.0^{*}$ \\
\hline \multicolumn{11}{|l|}{ Ethnic group } \\
\hline Akan & 41.0 & $36.7^{*}$ & 38.5 & $32.9^{*}$ & 41.9 & 40.7 & 41.5 & 39.9 & 47.9 & 41.1 \\
\hline Krou & 9.8 & 9.5 & 7.5 & 7.4 & 16.2 & 10.1 & 12.7 & 12.5 & 10.4 & 11.4 \\
\hline Mandé & 17.1 & 17.9 & 17.0 & 17.0 & 17.1 & $26.3 \dagger$ & 17.1 & 15.6 & 17.5 & 18.7 \\
\hline Voltaïque & 20.4 & $27.7^{* * *}$ & 22.1 & $32.6^{* * *}$ & 16.2 & 16.1 & 23.6 & 25.5 & 13.4 & $22.9 * *$ \\
\hline Other & 11.7 & $8.2^{* *}$ & 14.9 & $10.1^{* *}$ & 8.6 & 6.8 & 5.1 & 6.5 & 10.8 & $5.9+$ \\
\hline Total & 100.0 & 100.0 & 100.0 & 100.0 & 100.0 & 100.0 & 100.0 & 100.0 & 100.0 & 100.0 \\
\hline
\end{tabular}

${ }^{*}$ Differs significantly from females at $p<.05$. **Differs significantly from females at $p<.01 .{ }^{* * *}$ Differs significantly from females at $p<.001$. $†$ Differs significantly from females at $p<.10$. $\neq$ Data missing for two respondents on school/employment status and for four respondents on ethnic group. §Data missing for two respondents on school/employment status and for two respondents on ethnic

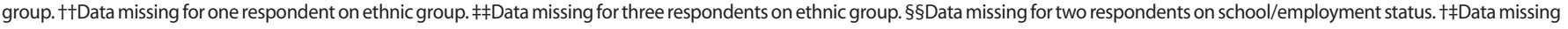
for two respondents on ethnic group. Note: $\mathrm{SD}=$ standard deviation.

had had a child before marriage, followed by both a brother and a sister, and, finally, a brother only. The patterns were similar for female and male respondents.

In the sample as a whole, females were more likely than males to be from Abidjan, whereas the opposite was true for Korhogo (Table 1). Moreover, females were generally younger and less educated than males. Overall, males were significantly more likely than females to currently be in school and significantly less likely to be employed or to be neither working nor in school. In each of the four study groups, at least half of males were still in school, whereas the distribution of females across schooling and employment categories was more balanced. Among the four sibling categories, the group who had no sibling with a history of premarital childbearing had the greatest number of social and demographic characteristics on which the proportions of females and males differed significantly.

Other descriptive statistics (not shown) indicate that most respondents ascribed high importance to their siblings' opinion about their sexual behavior ( $78 \%$ of female respondents and $77 \%$ of male respondents) and thought their siblings would approve if they abstained from sex until marriage ( $82 \%$ of female respondents and $74 \%$ of male respondents). Siblings were the most commonly reported type of relative with whom female (16\%) and male (18\%) respondents had spoken at least once in the past year about avoiding or delaying sex, followed by respondents' mother (reported by $8 \%$ of females and $5 \%$ of males).

During childhood, $56 \%$ of females and $59 \%$ of males had lived with both parents; $10 \%$ and $12 \%$, respectively, had lived with their father only. The proportions raised by a nonparental relative, such as an aunt, were $33 \%$ and $27 \%$, respectively. Substantial proportions of females and males (31\% and $13 \%$, respectively) reported having no close friends.

Large proportions of females and males ( $72 \%$ and $71 \%$, respectively) reported ever having had a boyfriend or girlfriend; $61 \%$ of females and $55 \%$ of males reported having such a partner at the time of the survey (Table 2, page 58). Overall, $68 \%$ of participants had ever had sex; the proportion did not differ significantly by gender. The mean age at first sex among sexually experienced youths was 16-17 years. 


\begin{tabular}{|c|c|c|c|c|c|c|c|c|c|c|}
\hline \multirow[t]{3}{*}{ Characteristic } & \multirow{2}{*}{\multicolumn{2}{|c|}{ All respondents }} & \multicolumn{8}{|c|}{ Respondents, according to sibling with premarital birth } \\
\hline & & & \multicolumn{2}{|c|}{ None/no siblings } & \multicolumn{2}{|c|}{ Brother(s) only } & \multicolumn{2}{|c|}{ Sister(s) only } & \multicolumn{2}{|c|}{ Brother(s) and sister(s) } \\
\hline & $\begin{array}{l}\text { Female } \\
(\mathrm{N}=1,395) \neq\end{array}$ & $\begin{array}{l}\text { Male } \\
(\mathrm{N}=1,242) \S\end{array}$ & $\begin{array}{l}\text { Female } \\
(\mathrm{N}=760)+\dagger\end{array}$ & $\begin{array}{l}\text { Male } \\
(\mathrm{N}=623) \neq \neq\end{array}$ & $\begin{array}{l}\text { Female } \\
(\mathrm{N}=117)\end{array}$ & $\begin{array}{l}\text { Male } \\
(\mathrm{N}=118) \S \S\end{array}$ & $\begin{array}{l}\text { Female } \\
(\mathrm{N}=278) \dagger \neq\end{array}$ & $\begin{array}{l}\text { Male } \\
(N=263)\end{array}$ & $\begin{array}{l}\text { Female } \\
(\mathrm{N}=240) \dagger \S\end{array}$ & $\begin{array}{l}\text { Male } \\
(\mathrm{N}=238) \neq \dagger\end{array}$ \\
\hline $\begin{array}{l}\text { Ever had } \\
\text { a boyfriend/ } \\
\text { girlfriend (\%) }\end{array}$ & 72.1 & 71.2 & 63.9 & 62.9 & 77.8 & 76.3 & 80.2 & $73.8+$ & 85.8 & 87.4 \\
\hline $\begin{array}{l}\text { Currently has } \\
\text { a boyfriend/ } \\
\text { girlfriend (\%) }\end{array}$ & 60.9 & $54.7^{* * *}$ & 53.4 & $48.8+$ & 63.3 & 63.3 & 67.8 & $53.6^{* * *}$ & 76.0 & $67.1^{*}$ \\
\hline Ever had sex (\%) & 68.1 & 67.7 & 59.7 & 58.0 & 72.7 & 75.4 & 75.9 & 70.7 & 83.3 & 86.1 \\
\hline \multicolumn{11}{|c|}{ Age at first sex (yrs.) $\neq \S$} \\
\hline Mean (SD) & $16.6(1.8)$ & $16.2(2.2)^{* * *}$ & $16.6(1.9)$ & $16.2(2.3)^{* * *}$ & $16.8(1.9)$ & $16.1(2.1)^{* *}$ & $16.5(1.7)$ & $16.4(2.1)$ & $16.6(1.7)$ & $16.1(2.2)^{* *}$ \\
\hline Median (range) & $17(7-23)$ & $16(8-24)$ & $17(7-22)$ & $16(8-24)$ & $17(12-23)$ & $16(12-21)$ & $17(11-22)$ & $17(9-21)$ & $17(11-21)$ & $16(10-23)$ \\
\hline
\end{tabular}

*Differs significantly from females at $p<.05$. **Differs significantly from females at $p<.01$. ***Differs significantly from females at $p<.001$. $†$ Differs significantly from females at $p<.10$. $\neq$ Data missing for one respondent on "ever had a boyfriend" and for 10 respondents on "currently has a boyfriend." §Data missing for six respondents on "currently has a girlfriend." $+†$ Data missing for one respondent on "ever had a boyfriend" and for five respondents on "currently has a boyfriend." ‡‡Data missing for four respondents on "currently has a girlfriend." §§Data missing for one

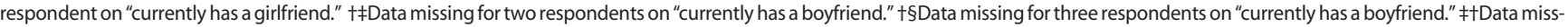
ing for one respondent on "currently has a girlfriend." ‡§Among sexually experienced respondents. Note: SD=standard deviation.

\section{Life-Table Survival Analysis}

In the life-table survival analyses for each gender (Figures 2 and 3), the probability of remaining sexually inexperienced generally was lower among persons who had at least one sibling with a premarital birth than among those with no such sibling. Beginning in the middle teenage years, the females with the lowest probability of remaining sexually inexperienced were those who had both a brother and a sister with a history of premarital childbearing; again beginning in middle adolescence, females with sister-only premarital childbearing had a probability lower than that of females who reported brother-only premarital childbearing (Figure 2). Among males, those who had at least one sibling of each gender with a history of premarital childbearing had the lowest probability of remaining sexually

FIGURE 2. Probability of remaining sexually inexperienced among female youth, by age, according to siblings' history of premarital childbearing

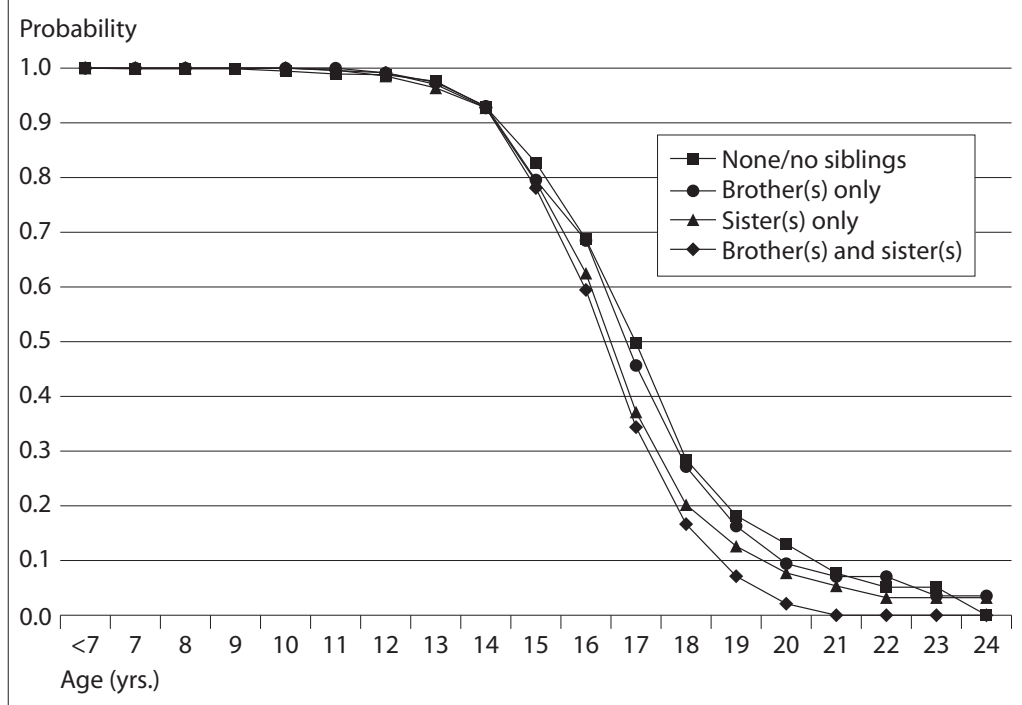

Note: Differences among groups significant at $\mathrm{p}<.001$, according to the log-rank test. inexperienced throughout the teenage years (Figure 3). In both the male and female analyses, log-rank tests of homogeneity found statistically significant differences among the study groups. Differences among sibling categories seem more pronounced for males than for females.

Within each of the four sibling categories, males' probability of remaining sexually inexperienced tended to be lower than that for females through about middle adolescence. Thereafter, females' probability tended to be lower than that of males. The one exception was participants with one or more brothers, but no sisters, with a history of premarital childbearing: In that study group, males' probability of never having had sex remained lower than that for females throughout late adolescence and early adulthood.

\section{Multivariate Cox Regression Analyses}

Multivariate Cox regressions with backward selection were conducted for each gender to examine the association between sibling category and respondents' initiation of sex by age 17 -the median age at first sex in the sample-and by age 24 , each in the presence of other potential explanatory variables. In the final models (Table 3 and Table 4, page 60), only two variables were associated with sexual experience for both females and males. Female and male respondents who believed they could definitely resist having sex with someone they had known for more than three months were significantly less likely than others to be sexually experienced by age 17 and by age 24. On the other hand, female and male youth who thought most or all of their single, close male friends had ever had sex were more likely than other youth to be sexually experienced themselves by age 17; for sex by age 24 , this variable was significant for males only. As for single, close female friends, the perception that most or all of them had ever had sex was associated with females' sexual debut by ages 17 and 24 and with males' sexual debut by age 24 . In addition, for females only, the relative risks of 
sexual debut by ages 17 and 24 were significantly increased among respondents who had no close female friends or who did not know whether their single, close female friends had ever had sex, compared with respondents who thought none or only a few of their single, close female friends had ever had sex (Table 3).

Several variables were statistically significant for one gender only. For females, having more than a secondary education instead of a primary education or less, or currently living with their father only instead of both parents and believing that a pregnancy could jeopardize their professional ambitions were each associated with reduced relative risks of sexual debut by ages 17 and 24. In contrast, being of the Krou ethnic group, compared with the Akan or Mandé, and having lived with nonparental relatives instead of both parents during childhood were associated with elevated risks of sexual debut by ages 17 and 24 .

TABLE 3. Among female youth, adjusted relative risk, from Cox regressions, of having had sex by age 17 and by age 24, according to selected variables

Variable

Relative risk of sex

\begin{tabular}{|c|c|c|}
\hline & $\begin{array}{l}\text { By age } 17 \\
(\mathrm{~N}=1,367)\end{array}$ & $\begin{array}{l}\text { By age } 24 \\
(\mathrm{~N}=1,370)\end{array}$ \\
\hline \multicolumn{3}{|l|}{ CHARACTERISTICS } \\
\hline \multicolumn{3}{|l|}{ Educational level } \\
\hline sprimary (ref) & 1.00 & 1.00 \\
\hline Secondary & $0.83^{*}$ & 0.94 \\
\hline$>$ secondary & $0.39^{* * *}$ & $0.53^{* * *}$ \\
\hline \multicolumn{3}{|l|}{ Ethnic group } \\
\hline Akan/Mandé & 1.00 & 1.00 \\
\hline Krou & $1.55^{* * *}$ & $1.42^{* *}$ \\
\hline Voltaïque & $1.21 \dagger$ & 1.09 \\
\hline Other & $0.78+$ & $0.77^{*}$ \\
\hline \multicolumn{3}{|c|}{ Whom respondent lived with before age 12} \\
\hline Both parents (ref) & 1.00 & 1.00 \\
\hline Father only & 1.25 & $1.27 \dagger$ \\
\hline Other relatives & $1.28^{* *}$ & $1.28^{* *}$ \\
\hline Other & 0.96 & 0.95 \\
\hline \multicolumn{3}{|c|}{ Whom respondent lives with now } \\
\hline Both parents (ref) & 1.00 & 1.00 \\
\hline Father only & $0.65^{*}$ & $0.74^{*}$ \\
\hline Other & 0.95 & 1.02 \\
\hline
\end{tabular}

Other

PERCEPTIONS

A pregnancy could jeopardize professional ambitions

Somewhat agrees/disagrees/

$\begin{array}{lll}\text { does not know (ref) } & 1.00 & 1.00\end{array}$

Strongly agrees $\quad 0.76^{* *} \quad 0.75^{* * *}$

Could resist having sex with somebody known for $>3$ mos.

$\begin{array}{lll}\text { Maybe/no/does not know (ref) } & 1.00 & 1.00\end{array}$

$\begin{array}{lll}\text { Yes, definitely } & 0.75^{* * *} & 0.74^{* * *}\end{array}$

No. of single, close male friends who have had sex

None/a few (ref) $\quad 1.00 \quad$ na

Most/all $2.18^{*}$ na

Has no close male friends/does not know 1.91† na

No. of single, close female friends who have had sex $\begin{array}{lll}\text { None/a few (ref) } & 1.00 & 1.00\end{array}$

Most/all $\quad 1.80^{* * *} \quad 2.19^{* * *}$

Has no close female friends/ $1.80^{* * *}-19^{* * *}$

does not know $1.47^{*} \quad 1.73^{* * *}$

${ }^{*} \mathrm{p}<.05 .{ }^{* *} \mathrm{p}<.01 .{ }^{* * *} \mathrm{p}<.001 .+\mathrm{p}<.10$. Includes informal schooling only and does not know. Notes: ref=reference category. na $=$ not applicable.
FIGURE 3. Probability of remaining sexually inexperienced among male youth, by age, according to siblings' history of premarital childbearing

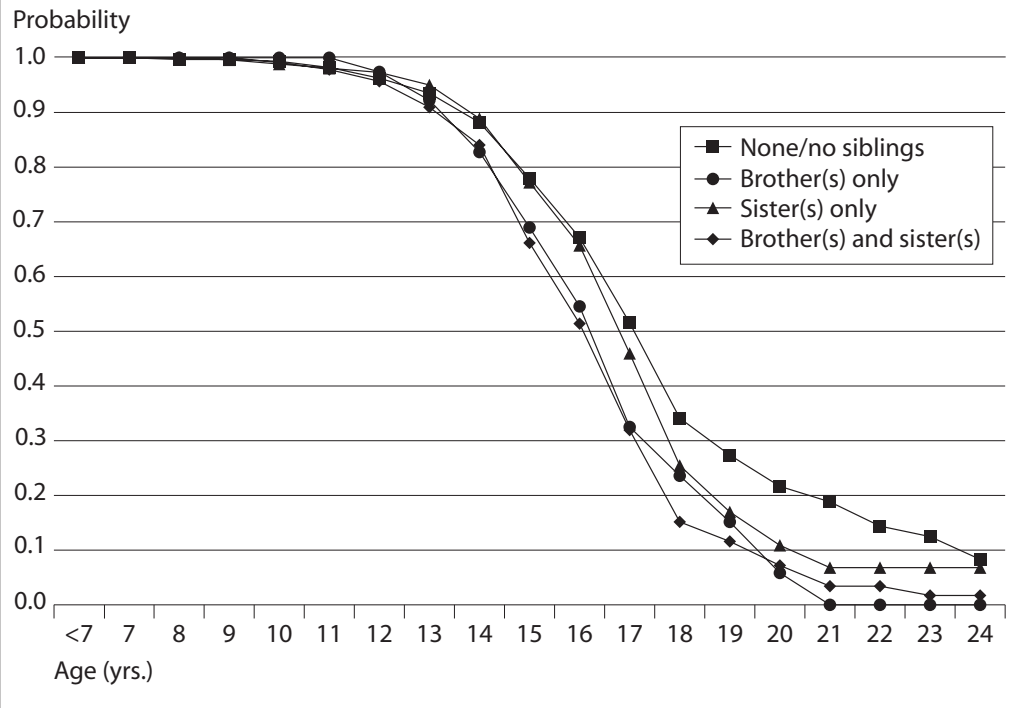

Note: Differences among groups significant at $\mathrm{p}<.001$, according to the log-rank test.

For males, the perceived ability to resist having sex with somebody the respondent had known for only a few days or with someone whom the respondent loved was associated with a decreased relative risk of sexual debut by age 24; the perception that close friends approved of the respondent's abstaining from sex until marriage was associated with a decreased relative risk of sexual initiation by ages 17 and 24 (Table 4). Males' sexual initiation by age 24 was positively associated with perceiving a moderate personal risk of AIDS. In addition, males who had a brother only or a brother and a sister who had experienced premarital childbearing were more likely than those with no sibling who had a history of premarital birth to have engaged in sex by ages 17 and 24. Among all the variables assessed in the multivariate analysis for males, male siblings' history of premarital childbearing was associated with the second-highest relative risk for sexual experience; males' perception that most or all of their single, close male friends were sexually experienced was associated with the highest relative risk in the analysis. No variables pertaining to parents or other nonsibling relatives were included in the final multivariate models.

\section{DISCUSSION}

The finding of a positive association between males' earlier age at sexual debut and their siblings' history of premarital childbearing is consistent with the results of other studies. ${ }^{17}$ One explanation may be that, in accordance with social norms, premarital childbearing is not considered shameful or disastrous for males; therefore, when male youth who have children outside of marriage are not sanctioned, their brothers may see no reason not to do so as well. Furthermore, from a social learning theory perspective, the younger brother who perceives fatherhood as beneficial may be encouraged to engage in sexual activity (and have children).

At the same time, it is intriguing that no association was 


\begin{tabular}{|c|c|c|}
\hline Variable & Relative risl & of sex \\
\hline & $\begin{array}{l}\text { By age } 17 \\
(\mathrm{~N}=1,197)\end{array}$ & $\begin{array}{l}\text { By age } 24 \\
(\mathrm{~N}=1,192)\end{array}$ \\
\hline PERCEPTIONS & & \\
\hline $\begin{array}{l}\text { Could resist having sex with somebod } \\
\text { a few days }\end{array}$ & ly known for & only \\
\hline Maybe/no/does not know (ref) & na & 1.00 \\
\hline Yes, definitely & na & $0.83^{*}$ \\
\hline Could resist having sex with somebod & ly known for & 3 mos. \\
\hline Maybe/no/does not know (ref) & 1.00 & 1.00 \\
\hline Yes, definitely & $0.69^{* * *}$ & $0.77^{* *}$ \\
\hline Could resist having sex with somebod & ly "loved de & \\
\hline Maybe/no/does not know (ref) & na & 1.00 \\
\hline Yes, definitely & na & $0.80^{*}$ \\
\hline Risk of AIDS & & \\
\hline None (ref) & na & 1.00 \\
\hline Moderate & na & $1.28^{*}$ \\
\hline High/has AIDS & na & $1.21 \dagger$ \\
\hline Does not know & na & 0.88 \\
\hline No. of single, close male friends who $h$ & lave had sex & \\
\hline None/a few (ref) & 1.00 & 1.00 \\
\hline Most/all & $2.36^{* * *}$ & $2.02^{* * *}$ \\
\hline Has no close male friends/does not know & 1.08 & 1.09 \\
\hline No. of single, close female friends who & have had sc & \\
\hline None/a few (ref) & na & 1.00 \\
\hline Most/all & na & $1.41^{*}$ \\
\hline $\begin{array}{l}\text { Has no close female friends/ } \\
\text { does not know }\end{array}$ & na & 1.15 \\
\hline $\begin{array}{l}\text { Close friends' opinion of respondent's } \\
\text { sex until marriage }\end{array}$ & abstaining & om \\
\hline $\begin{array}{l}\text { Disapprove/has no close friends/ } \\
\text { does not know (ref) }\end{array}$ & 1.00 & 1.00 \\
\hline Approve & $0.79^{* *}$ & $0.83^{*}$ \\
\hline $\begin{array}{l}\text { SIBLINGS' CHARACTERISTIC } \\
\text { Siblings with a premarital birth }\end{array}$ & & \\
\hline None/has no siblings (ref) & 1.00 & 1.00 \\
\hline Brother(s) only & $1.37^{*}$ & $1.35^{*}$ \\
\hline Sister(s) only & 1.09 & $1.18+$ \\
\hline Brother(s) and sister(s) & $1.40^{* *}$ & $1.38^{* * *}$ \\
\hline
\end{tabular}

found between female siblings' behaviors. This finding contrasts with those reported by studies in Ghana and the United States. ${ }^{18}$ At least three factors may explain the lack of association after adjustment for other potential explanatory variables. First, as Tables 3 and 4 indicate, females, compared with males, had a higher number of personal characteristics associated with age at first sex. Many of these characteristics tend to be protective, including having an increased educational level, currently living with one's father only, perceiving that a pregnancy could jeopardize professional ambitions and believing in one's ability to resist having sex with someone known for more than three months.

This finding may, instead, be related to the fact that a higher proportion of females than males had been raised primarily by nonparental relatives. Females may thus have had a reduced likelihood of being raised with their siblings. Although characteristics of sibling relationships are unavail- able (e.g., importance of emotional support, competition, differential treatment by parents), one can assume that sisters living apart are less likely than sisters living together to have close bonds or considerably influence each other's behavior. Further studies are needed to better understand the gender differential in the association between siblings' premarital childbearing status and youths' age at first sex.

\section{Programmatic Implication}

On the basis of this study's findings, youth-oriented programs should consider sibling relationships-in particular, those between males-when developing intervention strategies. The following examples could be considered.

- Promote positive role modeling by older siblings. One possibility is a communication campaign that includes a sibling character who would adopt positive attitudes and behaviors, such as abstaining from sex until marriage and encouraging siblings to do the same, discussing sexuality and reproductive health issues with them and giving them good advice. The message would make clear that youth can be "cool" and have fun without jeopardizing their health and their future. Also, communication campaigns could be used to convey to youth the message that their siblings are looking up to them and are imitating their sexual and reproductive behaviors, much as they imitate their other behaviors.

- Involve positive peer role models. Peer education programs could involve youth who, despite pressure from their social and cultural environment, have adopted and maintained positive attitudes and behaviors, such as delaying their first sexual experience and therefore minimizing their exposure to the risks of premarital childbearing, HIV infection and other STIs. ${ }^{19}$ Having such role models speak out confidently may help dispel the notion that "everybody is doing it" and encourage others to follow their example and adopt or maintain less risky sexual behaviors.

- Develop accurate, appropriate messages. Program planners and administrators must realize that the information that they give through their peer educators and other communication strategies may diffuse through their target population to the siblings of those youth. Messages should be developed with this concern in mind. Thus, they should be simple, consistent and unambiguous.

- Convey to parents the importance of sibling influence. Some programs include strategies to reach parents and to encourage them to have greater involvement in their children's reproductive health education. Parents need to know that their children are likely to copy each other on issues such as sexuality and reproduction, just as they do in other activities. Parents must not only talk to their children about sexuality and reproduction, but must also be consistent in their attitudes and behavior with all their children.

\section{Study Limitations}

The survey on which this study is based asked respondents to recall events that may have happened in the distant past. Recall bias is therefore a possibility. Such bias is more likely among older youth, who may have been sexually active 
for several years and unable to remember precisely the timing of their first sexual intercourse. Another issue is the reliability of answers given by young people to such sensitive questions. ${ }^{20}$ In particular, responses obtained through faceto-face interviews have been shown to be distorted to be more socially acceptable. Males tend to inflate their sexual activity, whereas females tend to understate theirs. This pattern did not appear in the current data set.

Several authors have questioned the strength of associations found through cross-sectional analysis. ${ }^{21}$ They argue that this type of design may not adequately measure, and therefore account for, potential confounders. Unmeasured family background characteristics are examples of such confounders in analyses examining the possible determinants of teenagers' sexual behavior. For example, in an analysis of the consequences of teenage childbearing in the United States involving data from various longitudinal and panel studies on sets of sisters, Geronimus and Korenman found substantial differences between teenage mothers and older mothers on many variables studied, after adjustment for socioeconomic characteristics. ${ }^{22}$ After family background characteristics were added to their analyses, the estimates remained important but declined substantially. Finally, the estimates narrowed further after family background differences for sisters who had had births at different ages were included in the analysis. One can hypothesize that the relative risks calculated in this study would be smaller after adjustment for unmeasured background characteristics, but would the significance of the findings disappear? Longitudinal studies, comparison groups and propensity scores are better techniques for ascertaining causality. ${ }^{23}$

Finally, childbearing may occur long after the onset of sexual activity. A better way to gauge a brother's or sister's influence on a sibling's initiation of sexual relations may be to compare age at first sex for the two siblings. Unfortunately, however, information on siblings' age at first sex was unavailable. Moreover, no information was available on age differences between the respondents and the siblings who had experienced premarital childbearing. Therefore, questions remain on the direction of influence (if any): Did a sibling's premarital childbearing influence the youth's early sexual experimentation, or was it the other way around? Does it matter whether it is an older sibling or a younger one who had a premarital birth? Is the age difference between siblings an important factor? Further studies are needed to investigate these issues.

\section{CONCLUSION}

Delaying first sex among young people would substantially reduce the incidence and prevalence of unwanted pregnancies and STIs, including HIV infection, as well as their negative physical, social and cultural, and economic consequences. Programs that aim to delay first sex often use strategies involving peers or parents. Yet in this study, at least $13 \%$ of youth reported having no close friends, and youth more commonly had discussed sexual and reproductive matters with their siblings than with their parents or other relatives. Therefore, to increase the effectiveness of youth-oriented programs, strategies that also account for the potential influence of siblings should be developed.

\section{REFERENCES}

1. Bandura A, Social Learning Theory, Englewood Cliffs, NJ, USA: Prentice Hall, 1977.

2. Kirby D, Antecedents of Adolescent Sexual Risk-Taking, Pregnancy and Childbearing: Implications for Research and Programs, Washington, DC: National Campaign to Prevent Teen Pregnancy, 1999.

3. Karim AM et al., Reproductive health risk and protective factors among youth in Ghana, Washington, DC: Pathfinder International, FOCUS on Young Adults, 2002.

4. Kiragu K et al., Communicating about sex: adolescents and parents in Kenya, Sexual Health Exchange, 1996, No. 3, pp. 11-13.

5. Rwenge M, Facteurs contextuels des comportements sexuels: le cas des jeunes de la ville de Bamenda (Cameroun), Dakar, Senegal: Union for African Population Studies, Summary Report, 1999, No. 40.

6. Widmer ED, Influence of older siblings on initiation of sexual intercourse, Journal of Marriage and the Family, 1997, 59(4):928-938.

7. East PL, Do adolescent pregnancy and childbearing affect younger siblings? Family Planning Perspectives, 1996, 28(4):148-153.

8. Powers DA and Cherng-tay Hsueh J, Sibling models of socioecomonic effects on the timing of first premarital birth, Demography, 1997, 34(4): 493-511.

9. Miller BC and Bingham CR, Family configuration in relation to the sexual behavior of female adolescents, Journal of Marriage and the Family, 1989, 51(2):499-506

10. Meekers D, Consequences of premarital childbearing in Côte d'Ivoire, paper presented at the annual meeting of the Population Association of America, Toronto, Canada, May 3-5, 1990.

11. Population Reference Bureau, Youth in Sub-Saharan Africa: A Chartbook on Sexual Experience and Reproductive Health, Washington, DC: Measure Communication, 2001.

12. Babalola S, Awasum D and Quenum-Renaud B, The correlates of safe sex practices among Rwandan youth: a positive deviance approach, African Journal of AIDS Research, 2002, 1(1):11-21; Eaton L, Flisher AJ and Aarø LE, Unsafe sexual behavior in South African youth, Social Science E Medicine, 2003, 56(1):149-165; Gueye M, Castle S and Konaté $\mathrm{M}$, Timing of first intercourse among Malian adolescents: implications for contraceptive use, International Family Planning Perspectives, 2001, 27(2):56-62; Kaufman CE and Stavrou SE, "Bus fare, please": the economics of sex and gifts among adolescents in urban South Africa, Policy Research Division Working Paper, New York: Population Council, 2002, No. 166; Kiragu K, Youth and HIV/AIDS: can we avoid catastrophe? Population Reports, 2001, Series L, No. 12; Koster A, Kemp J and Offei A, Utilisation of reproductive health services by adolescent boys in the eastern region of Ghana, African Journal of Reproductive Health, 2001, 5(1):40-49; and Slap GB et al., Sexual behavior of adolescents in Nigeria: cross sectional survey of secondary school students, BMJ, 2003, 326(7379):15.

13. Zanou B et al., Connaissance, attitudes et comportement en matière d'IST/VIH/SIDA chez les jeunes citadins de Côte d'Ivoire, Rapport d'enquête, Santé familiale et prévention du Sida, Projet Régional pour l'Afrique de l'Ouest et Centrale, Abidjan, Côte d'Ivoire, 2002.

14. Zaba B et al., Estimation of levels and trends in age at first sex from surveys using survival analysis, WP-02-51, Measure Evaluation, Carolina Population Center, University of North Carolina at Chapel Hill, Chapel Hill, NC, USA, 2002.

15. Institut National de la Statistique, Côte d'Ivoire, et ORC Macro, Enquête Démographique et de Santé, Côte d'Ivoire 1998-1999, Calverton, MD, USA: Institut National de la Statistique et ORC Macro, 2001.

16. Bandura A, 1977, op. cit. (see reference 1).

17. Widmer ED, 1997, op. cit. (see reference 6) 
18. Karim AM et al., 2002, op. cit. (see reference 3); and East PL, 1996, op. cit. (see reference 7).

19. Babalola S, Awasum D and Quenum-Renaud B, 2002, op. cit. (see reference 12).

20. Mensch B, Hewett PC and Erulkar A, The reporting of sensitive behavior among adolescents: a methodological experiment in Kenya, Policy Research Division Working Paper, New York: Population Council, 2001 , No. 151; Delaunay V et al., Sexualité des adolescents: tendances récentes en milieu rural Sénégalais, Les Dossiers du CEPED, Paris: Centre sur la Population et le Développement, 2001, No. 65; and Eggleston E, Leitch $\mathrm{J}$ and Jackson J, Consistency of self-reports of sexual activity among young adolescents in Jamaica, International Family Planning Perspectives, 2000, 26(2):79-83.

21. Powers DA and Cherng-tay Hsueh J, 1997, op. cit. (see reference 8); Geronimus AT and Korenman S, The socioeconomic consequences of teen childbearing reconsidered, Quarterly Journal of Economics, 1992, 107(4):1187-1214; Rosenzweig MR and Wolpin KI, Sisters, siblings and mothers: the effect of teen-age childbearing on birth outcomes in a dynamic family context, Econometrica, 1995, 63(2):303-326; Guo G and VanWey LK, Sibship size and intellectual development: is the relationship causal? American Sociological Review, 1999, 64(2):169-187; and Rosenbaum PR and Rubin DB, The central role of the propensity score in observational studies for causal effects, Biometrika, 1983, 70(1): 41-55.

22. Geronimus AT and Korenman S, 1992, op. cit. (see reference 21).

23. Piotrow PT et al, Health Communication: Lessons from Family Planning and Reproductive Health, Westport, CT, USA: Praeger Publishers, 1997; Babalola S, Communication, ideation and contraceptive use in Burkina Faso: an application of the propensity score matching method, Journal of Family Planning and Reproductive Health Care (forthcoming); and Do MP and Kincaid DL, Impact of an entertainment-education television drama on health knowledge and behavior in Bangladesh: an application of the propensity score matching method, Journal of Health Communication (forthcoming).

\section{RESUMEN}

Contexto: La relación entre los comportamientos y actitudes sexuales y reproductivos de los jóvenes y los de sus pares y padres ha sido documentada; no obstante, es escasa la información que existe sobre la influencia de los hermanos y hermanas, especialmente en los países en desarrollo.

Métodos: Se analizaron datos de 1.395 mujeres y 1.242 hombres de 15-24 años de tres ciudades de Côte d'Ivoire. Se realizaron análisis de tablas de vida para examinar si un parto prenupcial de su hermana o hermano afectara la probabilidad de que los entrevistados permanecieran sin experiencia sexual. Se utilizaron análisis de regresión de riesgo proporcionales de Cox para calcular el riesgo relativo de los entrevistados de realizar su debut sexual antes de las edades de los 17 y 24 años.

Resultados: A cualquier edad entre los 15 y 24 años, la probabilidad de tablas de vida de que el joven (mujer u hombre) permanezca sin experiencia sexual fue generalmente más baja entre las personas que tenían por lo menos un hermano o hermana que había tenido un hijo antes del matrimonio que entre aquellos que no habían estado en una situación similar. En general, entre aquellos que tenían por lo menos un hermano o hermana que había tenido un parto prenupcial, la probabilidad era más baja si el hermano o hermanos y el entrevistado fueran del mismo género en vez del género opuesto, y la probabilidad era la más baja entre aquellos que tenían ambos, un hermano y una her- mana, con un hijo nacido antes del matrimonio. En los análisis multivariados correspondientes únicamente a los hombres, aquellos que tenían uno o más hermanos (pero no hermanas) que habian tenido un hijo antes del matrimonio, y aquellos que tenían por lo menos un hermano y una hermana con un hijo antes del matrimonio, presentaban unos riesgos elevados de haber tenido una experiencia sexual antes de las edades de los 17 y 24 años. Entre las mujeres, tener un hermano o hermana con un hijo antes del matrimonio no estuvo relacionado con dicho riesgo.

Conclusión: Los programas que procuran reducir la actividad sexual prenupcial entre los jóvenes deberán desarrollar estrategias que tengan en cuenta la influencia potencial que ejercen los hermanos y hermanas.

\section{RÉSUMÉ}

Contexte: L'association entre les attitudes et comportements sexuels et reproductifs des jeunes et ceux de leurs pairs et parents a été documentée. L'influence des frères et sœurs l'est cependant fort peu, dans les pays en développement surtout.

Méthodes: Les données relatives à 1.395 femmes et 1.242 hommes, âgés de 15 à 24 ans, de trois villes de Côte d'Ivoire ont été analysées. La probabilité pour les répondants de rester sexuellement inexpérimentés, en fonction des antécédents de procréation prénuptiale des frères et sœurs, a été évaluée par analyse des tables de mortalité. Le risque relatif d'initiation sexuelle des répondants avant l'âge de 17 ans et avant l'âge de 24 ans a été évalué par régressions multidimensionnelles de Cox.

Résultats: A tout âge entre 15 et 24 ans, la probabilité de demeurer sexuellement inexpérimenté/e s'est généralement avérée inférieure chez ceux et celles dont au moins un frère ou une sœur avait eu une naissance prénuptiale. En général, parmi ceux et celles dont au moins un frère ou une sour avait eu une naissance prénuptiale, la probabilité était inférieure si le répondant était du même sexe que le/la/les frère/s ou sœur/s en question. Elle atteignait son niveau le plus bas parmi ceux et celles dont un frère et une sour présentaient tous deux des antécédents de procréation prénuptiale. Dans l'analyse multivariée relative aux hommes, ceux dont un ou plusieurs frères (mais aucune sour) avaient connu une naissance prénuptiale et ceux dont au moins un frère et une sour répondaient à ce critère présentaient un risque élevé d'être sexuellement expérimentés avant 17 et 24 ans. Les antécédents de procréation des frères et sœurs ne sont pas liés à ce risque pour les femmes.

Conclusion: Les programmes cherchant à réduire l'activité sexuelle prénuptiale chez les jeunes doivent tenir compte dans leurs stratégies de l'influence potentielle exercée par les frères et sœurs.

\section{Acknowledgments}

The author thanks Basile Tambashe for facilitating access to the data; Stella Babalola, Jane Bertrand and Roger Dunwell for comments and suggestions on earlier drafts; and Brandon Howard for research assistance.

Author contact: nsidibe@jhuccp.org 